


OECD Working Papers on Finance, Insurance and Private Pensions No. 3

\title{
The Impact of the Financial
} Crisis on Defined Benefit Plans and the Need for Counter-Cyclical Funding

\section{Juan Yermo,}

Clara Severinson Regulations 


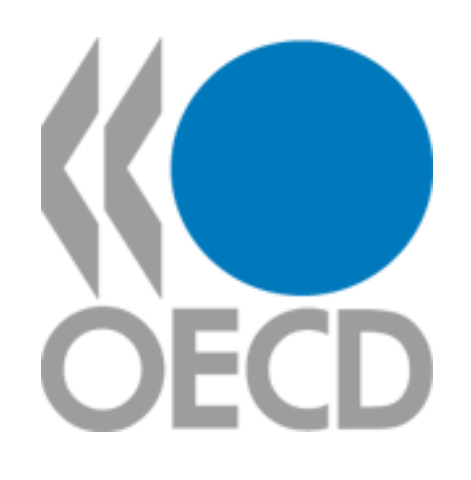

THE IMPACT OF THE FINANCIAL CRISIS ON DEFINED BENEFIT PLANS AND THE NEED
FOR COUNTER-CYCLICAL FUNDING REGULATIONS

Juan Yermo and Clara Severinson

July 2010

OECD WORKING PAPER ON FINANCE, INSURANCE AND PRIVATE PENSIONS

No. 3

Financial Affairs Division, Directorate for Financial and Enterprise Affairs

Organisation for Economic Co-operation and Development

2 Rue André Pascal, Paris 75116, France

www.oecd.org/daf/fin/wp 


\section{ABSTRACT/RÉSUMÉ}

\section{The Impact of the Financial Crisis on Defined Benefit Plans and the Need for Counter-Cyclical Funding Regulations}

Three essential goals of pension plan funding are the long-term viability, stability and security of member benefits. Reform of funding regulations for defined benefit (DB) pension schemes to make them more counter-cyclical in nature can help achieve these goals as well as make DB schemes more attractive to plan sponsors that are increasingly moving away from DB towards defined contribution plans. If designed properly, funding regulations could help maintain DB systems for the long-term and provide greater member security. Broadly speaking, DB funding regulations should (i) encourage deficit reduction contributions and appropriate build up of surplus when plan sponsor finances are strong; (ii) help maintain predictable costs and dampen volatility; and, (iii) give plan sponsors more control to manage risks and costs.

This paper discusses the impact of the crisis on DB pension schemes and the temporary responses taken by regulators to help ease financially strained plan sponsors. Furthermore, the paper presents suggestions to governments and policy-makers for making funding regulations more counter-cyclical in nature. Such measures could strengthen the security of DB benefits and help to maintain DB plans for future workers.

JEL codes: D21, E32, G01, G15, G23, G32, J33, K20, M40, M52

Key words: contribution, counter-cyclical, deficit, defined benefit, financial crisis, funding, marked-tomarket, regulation, surplus, pension

******

\section{Répercussions de la crise financière sur les plans à prestations définies et nécessité d'imposer des règles de financement à caractère anticyclique}

Le financement des plans de retraite obéit à trois objectifs essentiels : viabilité à long terme, stabilité et sécurité des prestations servies aux adhérents. Réformer les règles de financement des régimes de retraite à prestations définies pour renforcer leur nature anticyclique peut contribuer à atteindre ces objectifs et à rehausser leur attrait pour les promoteurs des plans qui s'en détournent de plus en plus au profit des dispositifs à cotisations définies. Si elles sont bien conçues, ces règles de financement pourraient permettre de préserver les systèmes à prestations définies sur un horizon lointain et d'apporter aux adhérents une sécurité accrue. D'une manière générale, les règles de financement des mécanismes à prestations définies doivent (i) favoriser la fixation de cotisations de nature à réduire le déficit de financement, ainsi que la constitution d'excédents à bon escient lorsque la situation financière du promoteur du plan est satisfaisante; (ii) favoriser la prévisibilité des coûts et atténuer les phénomènes d'instabilité ; et (iii) donner davantage de latitude aux promoteurs pour gérer les risques et les coûts.

Le présent document contient une analyse des répercussions de la crise sur les régimes de retraite à prestations définies, ainsi que des mesures provisoires adoptées par les autorités de tutelle pour aider les promoteurs de plans qui connaissent des difficultés financières. On y trouvera également des propositions utiles aux pouvoirs publics et aux décideurs pour accentuer le caractère anticyclique des règles de financement. De telles mesures pourraient accroître la sécurité des prestations servies par les dispositifs à prestations définies et contribuer à préserver ces plans pour les travailleurs de demain. 
Codes JEL : D21, E32, G01, G15, G23, G32, J33, K20, M40, M52

Mots clés : cotisation, anticyclique, déficit, prestations définies, crise financière, financement, valorisation au prix du marché, réglementation, excédent, retraite

\section{Copyright OECD, 2010}

Applications for permission to reproduce or translate all, or part of, this material should be made to: Head of Publications Service, OECD, 2 rue André-Pascal, 75775 Paris Cedex 16, France 


\title{
THE IMPACT OF THE FINANCIAL CRISIS ON DEFINED BENEFIT PLANS AND THE NEED FOR COUNTER-CYCLICAL FUNDING REGULATIONS
}

\author{
By Juan Yermo and Clara Severinson ${ }^{1}$
}

\section{Executive Summary}

Three essential goals of pension plan funding are the long-term viability, stability and security of member benefits. Reform of funding regulations for defined benefit (DB) pension schemes to make them more counter-cyclical in nature can help achieve these goals as well as make DB schemes more attractive to plan sponsors that are increasingly moving away from DB towards defined contribution (DC) plans. If designed properly, funding regulations could help maintain DB systems for the long-term and provide greater member security. Broadly speaking, DB funding regulations should:

- encourage deficit reduction contributions and appropriate build up of surplus when plan sponsor finances are strong;

- help maintain predictable costs and dampen volatility; and,

- $\quad$ give plan sponsors more control to manage risks and costs. ${ }^{2}$

This paper discusses the impact of the crisis on DB pension schemes and the temporary responses taken by regulators to help ease financially strained plan sponsors. Furthermore, the paper presents suggestions to governments and policy-makers for making funding regulations more counter-cyclical in nature. Such measures could strengthen the security of DB benefits and help to maintain DB plans for future workers. The policy measures suggested include the following:

- Avoid excessive reliance on current market values for purposes of determining contributions. Disclosure to plan stakeholders based on current market values of pension assets and liabilities may be appropriate to increase transparency, and the use of current market values could improve risk management. However, regulators should operate flexibly when reviewing a

\footnotetext{
${ }^{1}$ Juan Yermo is Head of the Private Pensions Unit within the OECD's Financial Affairs Division. Clara Severinson is an Administrator within the same Division. The views expressed are the sole responsibility of the author and do not reflect those of her organisation. The author is solely responsible for any errors.

${ }^{2} \mathrm{DB}$ and DC plans are defined in the official OECD classification as:

Defined contribution (DC) occupational pension plan: occupational pension plans under which the plan sponsor pays fixed contributions and has no legal or constructive obligation to pay further contributions to an ongoing plan in the event of unfavourable plan experience.
}

Defined benefit $(D B)$ occupational pension plan: occupational plans other than defined contributions plans. DB plans generally can be classified into one of three main types, "traditional", "mixed" and "hybrid" plans. 
scheme's funding position or regulators should enable pension funds and plan sponsors to dampen somewhat the volatility of market prices when determining contributions; ${ }^{3}$

- Set minimum funding levels or targets that are consistent with the goal of benefit security. In particular, the level of funding needed by pension funds in a particular country depends on what other type of security mechanisms are in place - such as pension guarantee or insurance schemes - to protect scheme assets and members from the pension fund's or plan sponsor's insolvency;

- Allow appropriate levels of over-funding in good economic times via more flexible tax ceilings. One possibility that could be explored in the wider context of country-specific regulation, is for maximum contribution or funding ceilings to span a multi-year period rather than be set on an annual basis to allow greater management of cash-flows by the plan sponsor. Governments should also consider raising the maximum level of surplus before contributions must be suspended;

- Limit Contribution Holidays and Plan Sponsor Access to Surplus. Regulators should consider restricting the extent to which plan sponsors can take contribution holidays, offer additional benefits or withdraw a portion of pension fund surplus, for example, only allowing them when a certain level of funding above the minimum level is reached;

- Encourage Stability of Long-Term Contribution Patterns via Appropriate Actuarial Methods. Actuarial funding methods should be transparent. The actuarial funding methods that lead to smoother contribution patterns could be encouraged by regulators;

- Incorporate flexibility into funding rules to reflect the overall volatility of funding valuations. While the primary goal of a pension plan is to provide secure benefits to plan members, funding regulations should aim at avoiding undue pressure on plan sponsors at times when their own profitability or even continuity is under pressure. For instance, regulators could take into account the overall volatility of funding levels when setting the recovery periods required for pension funds to eliminate funding deficits. The level of flexibility of funding rules will also depend on other factors such as the extent to which the fund can rely on additional plan sponsor contributions.

- Avoid over-regulation and maintain a stable regulatory environment. The regulatory framework needs to be robust in order to provide a high degree of benefit protection. It is also important to strike the right balance between stability and flexibility in funding rules. Changing rules too frequently can lead to additional volatility in pension funding. Policymakers should therefore avoid continuously changing and excessively complex regulation as this could discourage plan sponsors from making long-term pension promises.

The paper also considers the question of convergence in pension funding regulations. It considers that the international standardization of funding regulations is unlikely and that in any case it would risk being ill-fitting across jurisdictions. However, some convergence of over-arching funding principles to promote counter-cyclical features as discussed in this paper could strengthen DB systems. This could be complemented by general international best-practices and guidelines on how to determine minimum funding contributions and assets and liabilities and by further developing the OECD Guidelines on Funding and Benefit Security.

\footnotetext{
${ }^{3}$ A further way for plan sponsors to reduce contribution volatility could be explored with the use of asset-liability matching techniques. Such industry practice is beyond the scope of this paper.
} 


\section{Introduction}

Defined benefit (DB) pension plans were traditionally the main source of complementary pension provision in major OECD countries. In most jurisdictions, such plans offered a high level of income security for members after retirement. Over the last two decades, however, their role in private sector pension provision has diminished in various countries. The United Kingdom has probably experienced the sharpest decline in the importance of DB plans, with over 73 percent closed to new entrants. With few exceptions, the future of private pensions is looking increasingly of the defined contribution (DC) type, where individuals bear the main pension-related risks during at least their working life. The recent crisis, however, has highlighted the risks of a DC world where individuals are fully exposed to the vagaries of the market.

Funding regulations play a central role in the operation of DB arrangements, ensuring that benefit promises are backed by a sufficiently large pool of assets that are protected from the bankruptcy of the plan sponsor. But such regulations and their impact on plan sponsor cash flow are also a major driver of the extent to which plan sponsors continue to offer long-term pension promises. Plan sponsors worry about cost levels and volatility. Contributions to DB pension plans are notoriously difficult to predict and minimum and maximum limitations on contributions to pension funds may make sensible overfunding of DB systems difficult. Volatile costs and a high level of regulation of DB plans in comparison to the relatively predictable costs and lower levels of regulations of DC plans also make DC plans increasingly appealing to employers.

The long-term viability of DB plans and the security of members' pensions may be enhanced by a reform to certain aspects of funding regulations, but that is appropriate and complementary to protection mechanisms that may be in place. In particular, the sustainability and security of DB plans could be enhanced by funding regulations that are more counter-cyclical in nature. Funding regulations that encourage deficit reduction contributions and appropriate build up of surplus when plan sponsor finances are strong, that help maintain predictable costs and dampen volatility, and that give plan sponsors more control to manage risks and costs on a long-term basis will strengthen DB systems and will ultimately provide for greater member security. The crisis has triggered some temporary policy measures along these lines, but a more comprehensive reform of funding regulations is necessary in some countries.

This paper gives some broad guidelines as to how such reforms of funding legislation could be structured and what issues are important to keep in mind. However, regulators must be aware that legislation that may seem sensible when economic times are good may be politically unrealistic to enforce on cash-strapped plan sponsors during difficult financial times. Just as long-term pension promises must be protected, so must legislation be "recession-proof", while maintaining an appropriate level of flexibility to deal with changing circumstances.

Reform of funding regulations should also be considered within the broader regulatory context in which private pensions systems operate. In particular, policymakers should carefully consider the role of other mechanisms to protect DB pensions from the bankruptcy of the plan sponsor as this is one of the key risks that DB plan members and beneficiaries are ultimately exposed to. Various countries have introduced schemes to offer such benefit protection, but they also raise the cost to employers of DB promises. Policymakers should consider how to improve the design of these pension protection arrangements so that they offer efficient and effective protection. ${ }^{4}$

\footnotetext{
${ }^{4}$ For a discussion of guarantee schemes set up by governments, see Fiona Stewart, "Benefit Security Pension Fund Guarantee Schemes", OECD Working Papers on Insurance and Private Pensions, No. 5, January 2009. Andrew Slater and Con Keating, "Risk with everything? Pension cost and variability", BrightonRock Group, discuss the role of market solutions.
} 
Policymakers should also pay attention to reform in other policy areas in order to help improve the outlook for DB plans. Firstly, better risk management, covering the main risks that DB plans are exposed to, would both reduce the volatility in funding ratios and increase benefit security. Regulators should promote the use of asset-liability modeling and require the use of prudent, yet realistic assumptions when calculating liabilities, including up-to-date estimates of longevity risk exposure.

Secondly, regulations should encourage DB plans to integrate some degree of flexibility in benefit design in order to accommodate the long-term uncertainty involved in such contracts. Examples of such flexible features include benefits linked to life expectancy or indexation conditional on the financial situation of the pension plan. ${ }^{5}$ Such features could be applied to benefits being accrued by current employees, leaving pensioners with greater benefit security.

Thirdly, pension policymakers should pay more attention to international pension accounting standards and how they impact plan sponsor behaviour, as accounting standards are a major driving factor in the decision of many corporations to discontinue their DB pension plans. The global spread in recent years of accounting standards with significant marked-to-market components combined with periods of poor asset performance and low interest rates has brought pension plans into serious focus in corporate board rooms. Even companies with relatively modestly sized pension plans can have pension obligations that dwarf the size of other obligations in their financial statements. Marked-to-market accounting rules have arguably increased transparency and comparability of corporate financial statements. However, the effect of DB systems on volatile corporate profits as actualised by marked-to-market accounting rules may increasingly dominate over other arguably more fundamental issues such as long-term corporate profitability, corporate culture, the regulatory environment and long-term financing strategies as the biggest driver behind how and in what manner corporations remunerate their employees.

This preliminary note consists of three sections. Section I discusses the impact of the crisis on DB plans and pension protection schemes and describes the main regulatory reactions. Section II lays out some policy proposals to make funding rules more counter-cyclical. Section III, by way of conclusion, considers the extent to which convergence in funding rules is likely or indeed desirable.

\footnotetext{
${ }^{5}$ See Colin Pugh and Juan Yermo, "Funding Regulations and Risk Sharing”, OECD Working Paper on Insurance and Private Pensions No. 17, April 2008.
} 


\section{The Impact of the Financial Crisis on Defined Benefit Pension Plans And Regulatory Response}

\section{(i) Pension Plan Financials and Procyclicality}

The 2008 financial crisis had a major impact on global pension assets, with the OECD estimating declines of $\$ 5.4$ th (over 20\%) at the end of 2008. About $60 \%$ of OECD pension assets are in defined benefit and other plans which offer return or benefit guarantees. While markets partly recovered during 2009 , funding levels of defined benefit plans remain very low in some OECD countries.

Due to the nature of defined contribution plans, pension funds that are mainly defined contribution in nature would have been hit fully by the decrease in pension fund assets in 2008. Median funding levels on an accounting basis in defined benefit plans also decreased, but not to as an extreme extent as was experienced in defined contribution plans. Major 2008 asset losses experienced by defined benefit pension funds were partly offset in some countries due to corresponding decreases in the level of defined benefit obligations due to increases in the corporate bond yields used for valuation purposes. In 2009, countries experienced the opposite effect. Investment gains in 2009 were offset to some extent in several countries by increased defined benefit obligations due to decreases in corporate bond yields. Furthermore, some countries such as Australia experienced reduced investment returns due to adverse exchange rates movements.

The funding level of a defined benefit plan that is reported in the plan sponsor's financial statement can be very different than the funding level of the same plan as reported to the regulators for purposes of determining statutory contributions. The reason for this is that the funding level used for financial reporting purposes and that used to determine statutory contributions are often established using different assumptions and different actuarial methods. For instance, regulators often measure liabilities using country-specific risk-free rates such as government bond yields whereas the most widely-used accounting standards require long-term high-quality corporate bond rates.

For example, in the Netherlands, where pension funds must use a swap rate for funding purposes, the Central Bank estimated that on a regulatory basis, average pension plan assets exceeded plan obligations by $44 \%$ at the end of 2007 . At the end of 2008 , for regulatory purposes, average pension plan assets were $5 \%$ lower than average pension plan liabilities. ${ }^{6}$ These regulatory funding levels for Dutch pension funds are quite different from the funding levels reported on an accounting basis by plan sponsors as the latter are calculated using a different set of assumptions and are typically only available in the aggregated financial statements of publicly-traded companies. In comparison to the Dutch regulatory funding levels mentioned above, as of fiscal-year end 2007, the median publicly-traded Dutch company had aggregate pension assets that were $10 \%$ lower than its aggregate pension obligations, and $11 \%$ lower as of fiscal year-ending 2008 .

Corporate financial statements tend to publish the most readily available and internationally comparable funding information for companies' defined benefit pension plans. However, funding levels found in corporate financial statements are most often reported on a global aggregate basis and can only serve as a very broad indication of what has happened on a plan specific, country regulatory level. Chart 1 shows the median funding level of 2,100 publicly traded companies defined benefit obligations (DBO) as published in their annual financial statements as of their fiscal years ending 2007, 2008 and 2009. The data shows the median funding level for these companies' aggregate pension obligations and have been grouped by the companies' countries of domicile. The median percentage of underfunding for these

\footnotetext{
${ }^{6}$ Estimated funding ratios of pension funds, available at http://www.statistics.dnb.nl/popup.cgi?/statistics/excel/t8.8ek.xls
} 
companies deteriorated from $13 \%$ as of the fiscal year ending 2007 to $23 \%$ as of fiscal year ending 2008 to $26 \%$ as of fiscal year ending 2009.

It should be noted that certain aspects of widely-used pension accounting standards are controversial. For instance, large swings in funding levels can be caused by relatively small shift in bond rates, rather than by inherent changes to the solvency position of corporate-sponsored defined benefit pension plans.

Chart 1

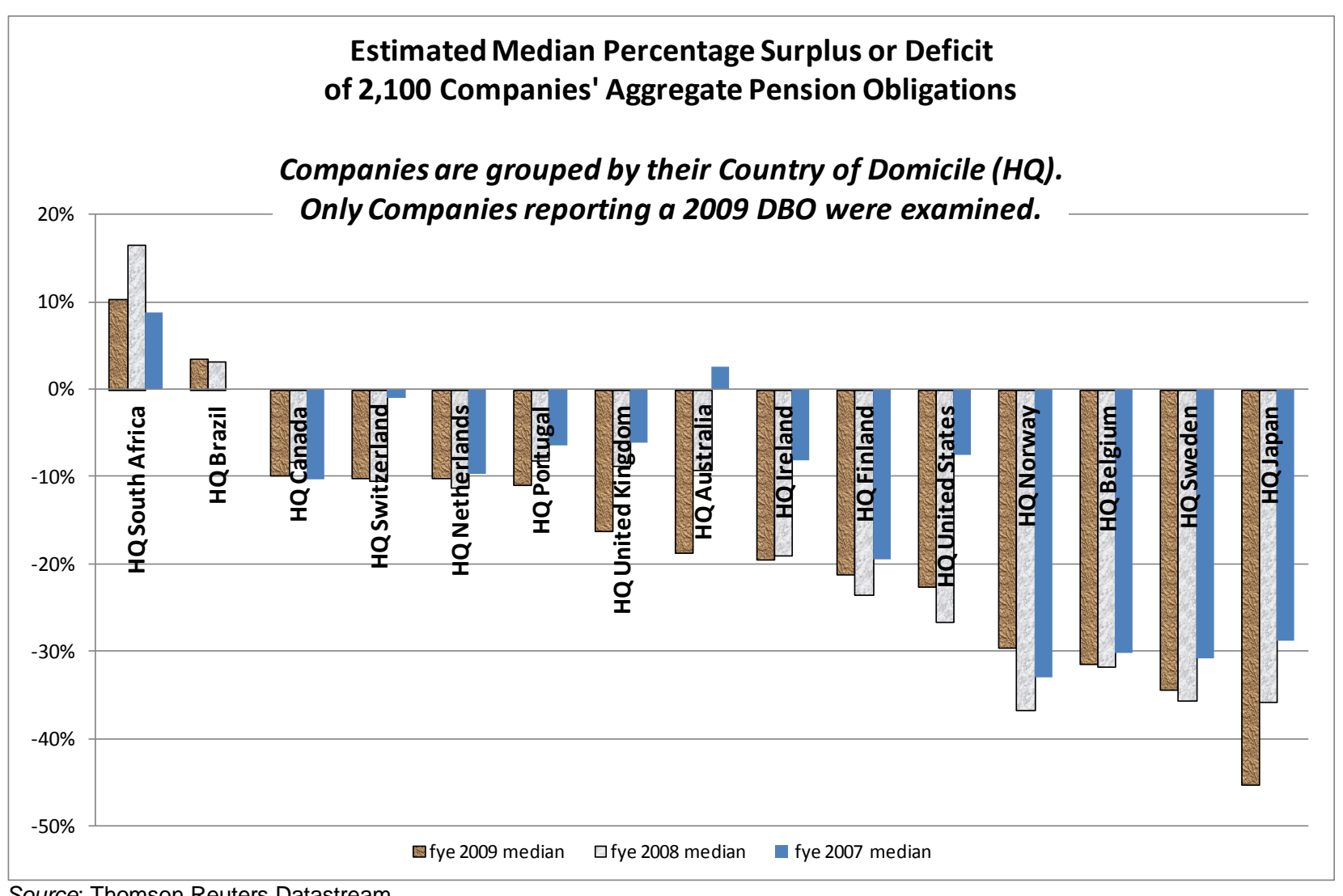

Source: Thomson Reuters Datastream

Rising underfunding of DB systems since 2007 in many countries has increased required contributions to DB systems. This has triggered calls to allow financially ailing plan sponsors some regulatory relief from their increased contribution requirements. Policymakers in some countries (e.g. Canada, Finland, Ireland, Japan, Netherlands, Norway, United Kingdom and the United States) have offered temporary funding relief to different degrees. Despite these initiatives, official figures for 2009 when recovery plans were launched - showed, as expected an increase in contribution rates relative to 2007 in certain countries with large DB systems such as Canada, the Netherlands and the United States. Chart 2 shows the total contributions reported by DB plans in some OECD countries between 2007 and 2009 as a percentage of Gross Domestic Product.

Forcing employers to increase their pension contributions during the economic downturn while allowing contribution holidays during good economic times makes funding regulations inherently procyclical. The drain on employers' cashflow at a time of low or negative company profitability can also have second order macroeconomic effects, via cuts in business investment, further worsening the outlook for employers. 
Procyclicality can also affect investment strategies. When equity prices boom, pension funds may not always rebalance their portfolio, leading to growing equity allocations in portfolios. During the downturn, on the other hand, pension funds may sell some of their equities, crystallizing any losses and driving markets down further. The use of market prices for calculating pension assets and liabilities (especially the application of spot discount rates) and the implementation of quantitative, risk-based funding requirements appear to have aggravated procyclicality in pension fund investments during the crisis in some countries such as Denmark, Finland and the Netherlands. While in Denmark and Finland regulatory changes were made to avoid sales of equities, mortgage bonds and other securities, pension funds in the Netherlands fell into a vicious circle as a result of the use of the spot swap curve to value their liabilities. Their heavy demand for long-term swaps put downward pressure on the long swap rate, which further intensified this demand. ${ }^{7}$ A more detailed discussion of the relative advantages and disadvantages of risk-based funding regulations is provided in part II of this paper.

\section{Chart 2}

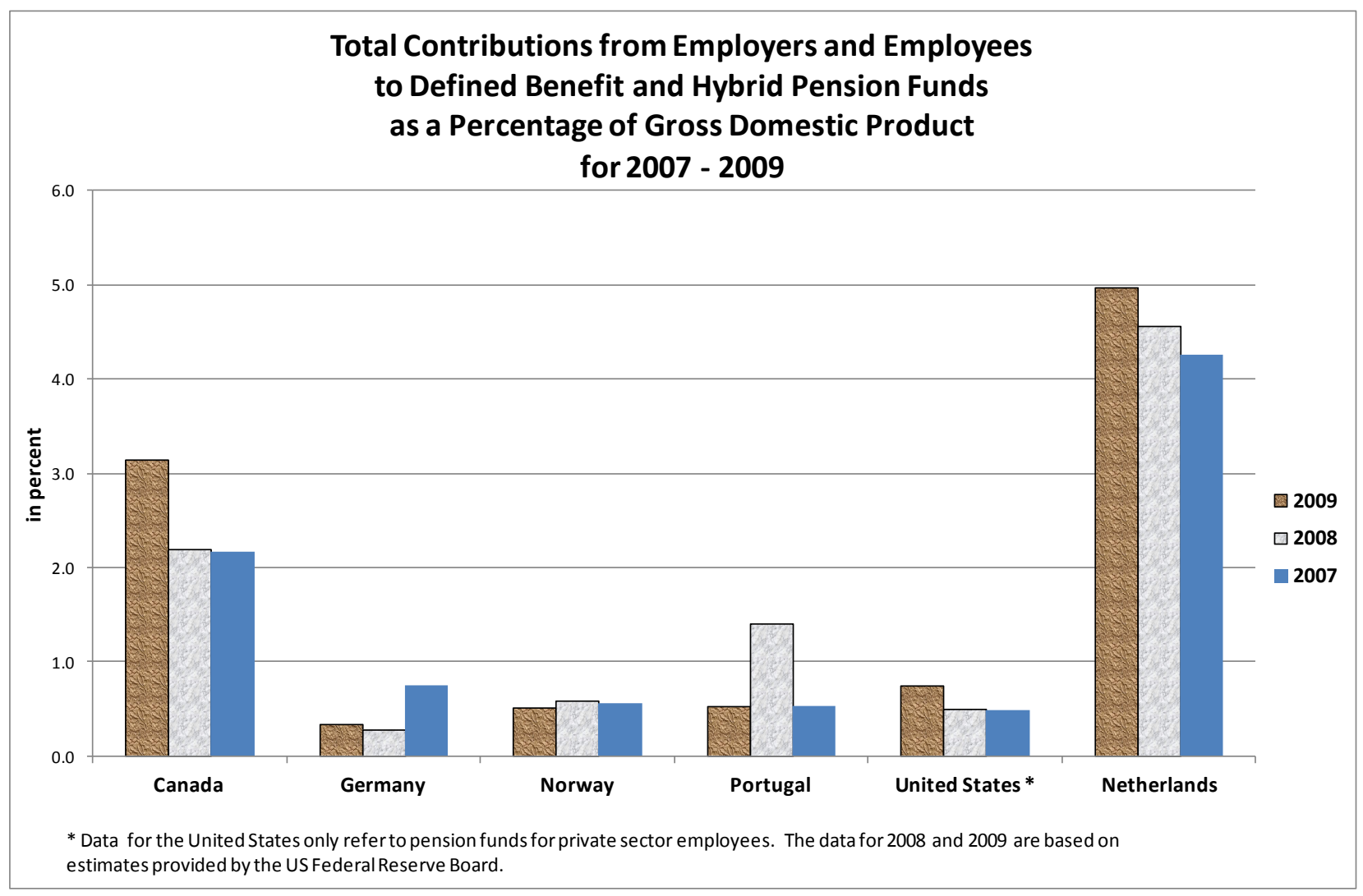

Source: OECD GPS

A third feature of procyclicality of DB plans is the movement of pension benefits in line with economic conditions. During a crisis DB plans are by nature and regulation more protected from reductions to benefits than DC ones. In DC plans, materialized declines in asset values (which occur for example when the member retires and buys an annuity) and reductions in contributions translate into lower pension benefits. However, benefits have been reduced also in some DB systems in response to the financial crisis. In particular, pension funds operating DB systems that include flexible features or

\footnotetext{
${ }^{7}$ Special Report of the Geneva Association Systemic Risk Working Group (March 2010), "Systemic Risk in Insurance: An Analysis of Insurance and Financial Stability, the Geneva Association, page 39.
} 
conditional benefits have used them actively in order to slow the growth of plan liabilities and hence improve funding ratios. For example, most Dutch pension funds have proposed to stop (conditional) benefit indexation for the next few years as part of their recovery plans.

\section{(ii) Regulatory Forbearance Initiatives}

Regulatory interventions during the crisis have aimed specifically at permitting pension funds and/or plan sponsors flexibility in meeting funding requirements and related regulations (see Table 1). These changes have avoided putting further pressure on companies' profitability and cashflow needs at a time of dire financial conditions which could lead to the closure of pension plans, or, in the face of extreme calls for pension contributions, could even force the sponsor into bankruptcy.

These regulatory changes have also allowed pension funds to maintain their long-term investment strategies and tempered procyclical and feedback effects in investment strategies. This has been most notable in countries - like Denmark and Finland - where there has been regulatory pressure on pension funds to sell some of their riskier assets such as equities and mortgage bonds. The decision to relax valuation and solvency rules in these countries helped prevent a major sell-off that would have been detrimental to the funds' long-term financial situation as would it have been a source of financial instability.

Table 1. Main funding forbearance initiatives for DB plans since $2007^{8}$

\begin{tabular}{|l|l|}
\hline Country & Regulatory measure \\
\hline Canada & $\begin{array}{l}\text { Federally regulated plans have had their recovery periods extended from 5 to 10 } \\
\text { years for deficiencies incurred in the 2008 plan year, subject to certain conditions. } \\
\text { Several provinces have also extended similar funding relief. }\end{array}$ \\
\hline Denmark & $\begin{array}{l}\text { In October 2008, the Financial Supervisory Authority (FSA) temporarily lifted the } \\
\text { requirement to use market interest rates to calculate pension companies' liabilities. } \\
\text { The supervisory traffic light system was also temporarily suspended and instead } \\
\text { pension companies had to submit quarterly reports detailing the use of reserves to } \\
\text { the FSA. }\end{array}$ \\
\hline Finland & $\begin{array}{l}\text { A new bill (passed in December 2008) aims at securing the solvency requirements of } \\
\text { pension funds without leading to forced sales of equities in a disadvantageous } \\
\text { market position, with these legal provisions remaining in place until the end of 2010. } \\
\text { The government is currently considering extending these measures until end 2012. }\end{array}$ \\
\hline Ireland & $\begin{array}{l}\text { The regulator has temporarily granted additional time for the preparation of funding } \\
\text { proposals, dealing as flexibly as possible with applications for approval of funding } \\
\text { plans, and is allowing longer periods for recovery plans (i.e., greater than ten years), } \\
\text { in appropriate circumstances and taking into account voluntary employer guarantees } \\
\text { in approving recovery plans. }\end{array}$ \\
\hline Japan & $\begin{array}{l}\text { In April 2009, the Japanese government announced a moratorium on contributions } \\
\text { by plan sponsors to cover under-funding of corporate pension plans. }\end{array}$ \\
\hline Netherlands & $\begin{array}{l}\text { Extension of the time required to submit recovery plans and lengthening of recovery } \\
\text { period for pension funds from three to five years. }\end{array}$ \\
\hline Norway & $\begin{array}{l}\text { Pension funds in Norway had 3 years to increase their premium reserves as a result } \\
\text { of new mortality statistics, but in light of the current crisis this period has been } \\
\text { extend to 5 years. }\end{array}$ \\
\hline
\end{tabular}

\footnotetext{
${ }^{8}$ Source: Pablo Antolín and Fiona Stewart, "Private Pensions and Policy Responses to the Financial and Economic Crisis", Working Papers on Insurance and Private Pensions, No. 36, April 2009, and OECD, "Policy Action in Private Occupational Pensions in Japan During the Economic Crisis of the 1990's", 1 July 2009.
} 


\begin{tabular}{|l|l|}
\hline Switzerland & $\begin{array}{l}\text { In October 2008, the Swiss government lowered the minimum return that pension } \\
\text { funds must pay their members from 2.75\% to 2\%. }\end{array}$ \\
\hline United States & $\begin{array}{l}\text { New US legislation in } 2008 \text { and } 2010 \text { easing the funding requirements for employer- } \\
\text { sponsored pension plans included in the 2006 Pension Protection Act by temporarily } \\
\text { extending the amortization period for annual funding shortfalls from } 7 \text { years to up to } \\
15 \text { years. }\end{array}$ \\
\hline $\begin{array}{l}\text { United } \\
\text { Kingdom }\end{array}$ & $\begin{array}{l}\text { UK used existing flexibilities within the funding regime to allow for re-assessment } \\
\text { of existing recovery plans and the possibility of back end loading. This flexible } \\
\text { approach can be more readily adaptable to the conditions of the time and not require } \\
\text { legislative change. }\end{array}$ \\
\hline
\end{tabular}

These temporary or built in adjustments to the prescribed regulatory framework raise some fundamental questions over the suitability of regulations and in particular valuation standards and funding rules. These issues are addressed in Section II of this paper.

\section{(iii) Impact of the Crisis on Pension Protection Schemes}

A few OECD countries (e.g. the Canadian province of Ontario, Germany, Japan, Sweden, Switzerland, United Kingdom, United States) have in place guarantee arrangements to protect benefits against the insolvency of the plan sponsor. ${ }^{9}$ These schemes have been tested by the financial crisis due to deteriorated plan sponsor finances and an increased number of insolvencies.

The Pension Benefit Guaranty Corporation experienced an increase in its total balance sheet deficit from USD 11.2 billion in fiscal year 2008 (as of 30 September 2008) to USD 21.9 billion as of fiscal yearend 2009. The PBGC's board, which is chaired by the Labor Secretary, has also revoked its February 2008 decision to increase its target equity exposure from $28 \%$ to $45 \%$ and include an allocation of $10 \%$ to alternatives (such as real estate and private equity).

Germany has made some structural changes to the financing of the PSVaG, the mutual insurance association of German employers that protects current beneficiaries and members with vested entitlements in the event of employer insolvency ${ }^{10}$, in response to rising costs. These changes came into effect in 2006. Historically, the PSVaG was mainly financed on a pay-as-you-go basis. Pension payments were financed in the year they occurred and the cost was spread across the insured plan sponsors. In 2006, the PSVaG set up a fund to cover past obligations that will be built up by employer contributions over a period of 15 years. The fund was set up in order to mitigate upward pressure on contributions due to a decreasing number of insured plan sponsors sharing the cost. Furthermore, the full value of future entitlements to pension payments will be financed in the year that a plan sponsor becomes insolvent by spreading the cost across all insured plan sponsors. The ratio of the PSVaG's assets to liabilities remained relatively stable as of year-end 2008 compared to year-end 2007. According to the PSVaG's 2009 annual report, in 2009, the PSVaG experienced an $80 \%$ increase in the number of reported insolvencies over the prior year and the number of people entitled to benefits from the PSVaG increased by over $800 \%$. Total contributions to the PSVaG for 2009 (including some contributions owed, but that have been smoothed over the next four years) were EUR 4,068.3 million compared to EUR 506.1 million in 2008.

\footnotetext{
${ }^{9}$ Stewart, F. (2007), "Benefit Security Pension Fund Guarantee Schemes", OECD Working Papers on Insurance and Private Pensions, No. 5, OECD Publishing.

${ }^{10}$ The insolvency coverage applies to the following types of implementing occupational retirement provisions: book reserves (Direktzusage), pension funds (Pensionsfonds), support funds (Unterstützungskasse) and under certain circumstances direct insurance (Direktversicherung).
} 
In the United Kingdom's Pension Protection Fund, the actuarial deficit worsened from GBP 517 million as of 31 March 2008 to GBP 1,230 million as of 31 March 2009.

The liabilities pre-funded for by the Pension Protection Fund in the United Kingdom include both deferred and pensioner benefits for all schemes accepted into the PPF and also for schemes in the assessment period which follows from the employer insolvency but before being accepted into the PPF. The PPF also makes provision for schemes where the Board of the PPF reasonably expects to receive an insolvency notice and be accepted. Therefore, the value of assets held by the PPF aims to be sufficient to pay the benefits for all pensioners and deferred members for schemes transferred to the PPF and also for where the PPF has made a prudent expectation of a claim. While the PPF has seen an increase in the number of claims, this has been less than was expected at the start of the crisis. The solvency position as at end March 2009 was $88 \%$ calculated on an actuarial basis, but is expected to have improved significantly since as financial markets have rebound.

In Sweden's PRI Pensionsgaranti (formerly called FPG), the total balance sheet surplus decreased from SEK 1,300 million as of 31 December 2007 to SEK 509 million as of 31 December 2008, but increased to SEK 1,482 million as of 31 December 2009. The risk-adjusted insurance exposure of PRI Pensionsgaranti increased from SEK 100,000 million in 2007 to SEK 107,000 million in 2008 to SEK 108,000 million in 2009. In the event of plan sponsor bankruptcy, PRI Pensionsgaranti buys out the associated liability of the pension scheme with an external insurance company. The net cost for claims against PRI Pensionsgaranti increased from SEK 15.0 million in 2007 to SEK 20.2 million in 2008 to SEK 63.9 million in 2009.

Chart 3 show the extent that total balance sheet assets exceed (or are less than) the total balance sheet liabilities of the national guarantee schemes discussed in this section as of fiscal year-end 2009 and 2008. The total balance sheet surplus (or deficit) worsened for Germany, the United Kingdom and the United States during that time, whereas Sweden's position improved. 


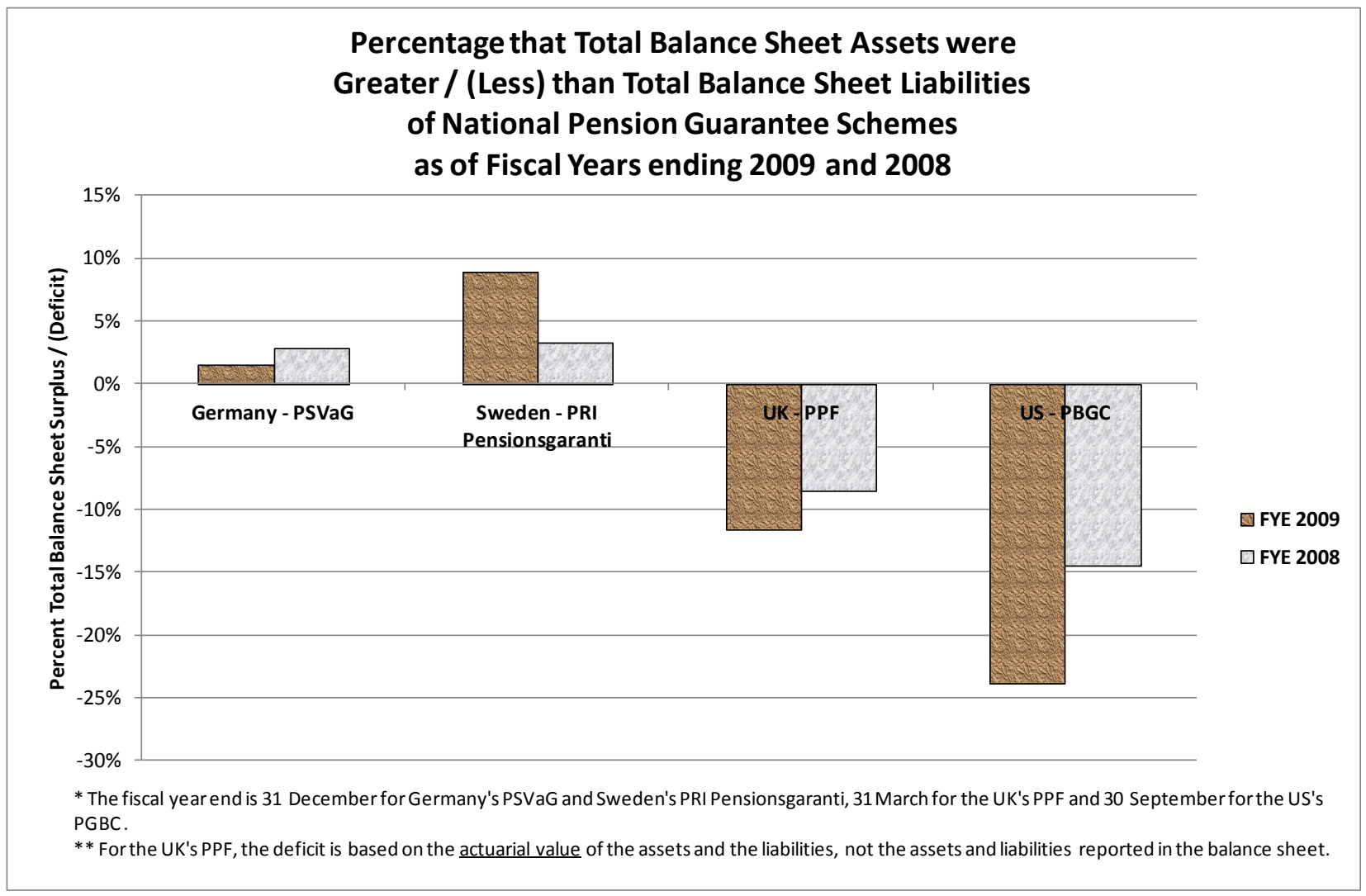

Source: 2009 and 2008 Annual Reports

\section{The Need for Counter-cyclical Funding Rules}

The potential for convergence towards more counter-cyclical funding regulations underpins the funding and benefit security guidelines of the OECD Recommendation on Core Principles on Occupational Pension Regulation. Guideline 3.16 states that "The legal provisions should not prevent funding methods that seek to dampen the short term volatility in firms' funding contributions", Guideline 3.17 allows for temporary reprieves to be granted by regulatory authorities, while Guideline 3.18 states that "funding rules should aim to be counter-cyclical, providing incentives to build reserves against market downturns".

However, in allowing for this flexibility in meeting funding requirements it is important to distinguish between temporary impacts of the economic cycle on sponsor cash flows and long-term, structural changes to strengthen the plan's funding status. In order to promote sufficiently high funding levels over the long term a number of different measures may be appropriate. It is important to remember that pension promises are very long-term in nature and funding rules should aim for the long-term financial viability, stability and security of DB systems.

The funding regulations in a selection of countries where DB pensions play a major role in private pension provision are described in Appendix I. While funding rules in these countries are varied, they tend to be characterized by three important components:

\footnotetext{
${ }^{11}$ See Guidelines 3.16-3.18 of the OECD Recommendation on Core Principles of Occupational Pension Regulation, June 2009, available at http://www.oecd.org/dataoecd/14/46/33619987.pdf
} 
- A minimum funding requirement that steers what amount must be contributed to the plan by the plan sponsor each year;

- A maximum funding requirement to protect tax revenues by prohibiting excessive funding levels and limiting the extent to which tax-advantaged contributions can be made into the plan;

- Surplus ownership guidelines which state to what extent excess funding can be recovered by the plan sponsor or can be used to increase benefits or reduce contributions.

Funding rules in most OECD countries have some element of counter-cyclicality built in. However, more counter-cyclicality is encouraged. Not only would this protect DB systems against economic downturns, but if correctly designed, counter-cyclical funding regulations can improve the attractiveness to plan sponsors of providing DB pension plans.

Following is a discussion of some regulatory initiatives that could be considered to promote procyclicality of funding rules for DB plans. The list of issues is not intended to be exhaustive or to cover all the issues as they are wide and complex and widely varied between jurisdictions. The list of issues below is, however, intended to discuss some of the key ways to promote counter-cyclicality in local regulations.

\section{(i) Avoid Excessive Reliance on Current Market Values for Purposes of Determining Contributions}

Firstly, it is important to keep in mind that the surplus or deficit used to determine the required contributions of a plan sponsor into a DB pension plan is a theoretical concept. A given level of liabilities is completely dependent on the assumptions chosen - assumptions such as how long people will continue working, how long they will live, what salary increases they will receive, rates of return. These assumptions span decades into the future are extremely unlikely to be borne out precisely in reality. An even slightly different set of assumptions can give a significantly different level of deficit or surplus. Any discussion on the financing of pension promises must keep clearly in mind that the plan sponsor's obligation at any specific point in time is a function of the estimated, unknown ultimate cost of very longterm pension promises.

Moreover, the high volatility of market prices especially for long-term securities, cannot always be justified on economic grounds. Indeed, prices may reflect market sentiment or "animal spirits" as well as some types of market inefficiencies stemming from, for example, low liquidity. Hence, their direct use in pension valuations may incorporate unnecessary noise into those valuations and cause excessive volatility in funding ratios and contributions.

The application of current market values to assets and liabilities may nevertheless be useful for improving risk management and in order to calculate the cost of wind-up (e.g. as a result of sponsor bankruptcy), the price of a buy-out by insurers and for disclosure purposes. In particular, the disclosure to plan stakeholders of assets and liabilities based on current market prices may therefore be appropriate in order to increase transparency and to show the potential shortfall (or excess, as the case may be) of funding in case of plan termination or bankruptcy of the plan sponsor. However, reflecting day-to-day market fluctuations in determining the annual contribution requirements of a pension plan to too great of an extent is counter-productive in maintaining the three important goals of pension plan funding: long-term viability, stability and security. 
The use of spot market discount rates to determine annual funding requirements, in combination with the risk profile that a pension fund has adopted, leads to high levels ${ }^{12}$ of volatility in funding ratio's, as was observed during the financial crisis. Funding regulations that require a market-level discount rate to determine funding contributions will, all else being equal, lead to much more volatile contribution levels than funding regulations that require a discount rate that is averaged over a longer period. As an example, rather than require the use of a spot government bond yield as of the funding valuation date to determine required contributions, the discount rate could be set as the average rate over the year preceding the funding valuation date. ${ }^{13}$ An averaging period for determining the discount rate would dampen the effect of short-term fluctuations in financial markets, but retain a direct link to current market rates in the contribution calculation. One of the values of smoothing is that it helps with predictability which is considered important by plan sponsors and creditors.

On the other hand, a smoothed discount rate reduces in some respect the transparency of the pure marked-to-market funded position at a particular point in time and may slow down the recovery of funding levels. The OECD Guidelines on Funding and Benefit Security state that whether discount rates are smoothed over time or marked-to-market, they should be prudently chosen taking into account the DB pension plan's demographic profile, risk and maturity structure. It may be appropriate, however, to have controls in place to ensure that the plan's funding level determined on a marked-to-market basis and the funding level determined on the regulatory basis used to determine required contributions do not become too different over an extended period of time as this could be an indication that certain aspects of the funding valuation requirements, such as for example the assumptions, are too optimistic or pessimistic. With regard to policy reactions, using a smoothed discount rate would make it more difficult to see the development of an interest rate trend, which in turn could lead to lagged responses. For instance, the marked-to-market funding position of a pension fund could be rapidly decreasing, whereas the funding level based on a smoothed discount rate could still be relatively stable.

Some countries like Japan and the United States use smoothed discount rates in order to dampen the effect of market volatility on contribution levels. There are calls in other countries like the Netherlands to also apply such smoothing to discount rates in order to, among other reasons, avoid large, rushed changes in funding and investment strategies that may be counterproductive from a long-term perspective. The temporary suspension of mark-to-market valuation of Danish pension companies' liabilities in October 2008 was also driven by a need to avoid fire sales of mortgage bonds and equities as solvency levels had reached a critical level. In the UK, discount rates are required to be chosen prudently taking note of the current market rates but not by using market rates directly to avoid high levels of volatility. UK discount rates must also take note of the time horizon of the liabilities and a prudent adjustment to be made taking account of the asset portfolio and sponsor covenant.

Another consideration to be taken into account when determining to what extent current market levels should be reflected in contribution requirements is to what extent plan assets should be smoothed when determining the plan's deficit or surplus. The OECD Guidelines on Pension Fund Asset Management ${ }^{14}$ state that pension fund assets should be valued on a proper, transparent and disclosed basis. The use of appropriate smoothing techniques to determine assets for funding purposes is consistent with OECD

\footnotetext{
${ }^{12}$ It is possible for a pension fund to hedge their investment risks, so that the value of the assets increases when liabilities increase (due to dropping interest rates). In fact, hedging can largely reduce the volatility of the funding ratio.

${ }^{13}$ A recommendation to smooth discount rates over the last quarter was made to the IASB's international accounting standard, IAS19, in a report by Samuel Sender, "IAS 19: Penalising Changes Ahead", EDHEC, September 2009.

${ }^{14}$ http://www.oecd.org/dataoecd/59/53/36316399.pdf
} 
recommendations. However, if the smoothing of asset prices is used, regulators and supervisors should make sure that they understand the potential impact of such techniques on plan funding levels, risk management as well as the members' perception that the plan is adequately secure. The smoothing technique used for pension assets should also be consistent with that used for pension liabilities when determining contribution requirements.

The Canadian government's recent funding reform follows this principle. In June 2010, Canada formally adopted a new methodology for the determination of minimum funding requirements for defined benefit plans that acts to mitigate the pro-cyclicality of the prior funding regime. The revised methodology establishes minimum funding requirements on a solvency basis that will use average - rather than current solvency ratios to determine minimum funding requirements. The average solvency position of the plan for funding purposes is defined as the average of the solvency ratios over three years, i.e. the current and previous two years. The three solvency ratios used in the determination of the average will be based on the market value of plan assets. The plan sponsor will be required to remit a minimum of 20 per cent of the deficit determined on this basis each year. This measure is intended mitigate the effects of short-term fluctuations in the value of plan assets and liabilities on solvency funding requirements.. ${ }^{15}$

Smoothing in itself does have limitations, especially if smoothing is applied over periods that are too long or if proper controls are not in place to identify pension plans that are in serious financial difficulties. For example, prior to passage of the Pension Protection Act of 2006, plans in the United States were permitted to smooth assets over five years and to discount liabilities using a five-year weighted average of interest rates. This smoothing produced a distorted picture of the financial health of plans during the early 2000 s and led to very inadequate minimum funding contributions. This was a significant factor in the termination of the plans of United Airlines, US Airways, and Bethlehem Steel, all of which continued to increase benefits to members even though they were significantly underfunded on a termination basis. The United States' Administration at that time strongly urged the Congress to reduce the permitted smoothing in the funding rules and the Pension Protection Act now prescribes two to three-year smoothing for asset values and interest rates for discount liabilities.

\section{(ii) Set Minimum Funding Levels or Funding Targets that are Consistent with the Goal of Benefit Security}

National funding requirements generally have minimum requirements and funding targets that steers what the plan sponsor must contribute to the plan each year. Typically, minimum funding requirements are determined by one of the following three approaches: (i) a detailed formula approach that is applied on a prescriptive basis for each fund, taking into account the difference between the fund's current funding level and the target level; (ii) contribution requirement that are more principles based where contributions and target funding levels are determined on a fund-specific basis; or, (iii) contribution requirements that are based on a quantitative assessment of the risk-profile of each specific pension fund. In this approach, pension funds with risky assets are required to have higher funding levels in comparison to pension funds with less risky assets.

It is important to keep in mind that it is by no means obvious where to set the target funding level or the minimum contribution requirements for a company-sponsored DB pension plan. Countries set different targets and minimum contribution levels for a variety of reasons based on the structure of the domestic pension system. In particular, the level of funding needed by pension funds in a particular country depends on what other type of security mechanisms - such as pension guarantee or insurance schemes - are in place to protect scheme assets and members and beneficiaries from the pension fund

\footnotetext{
${ }^{15}$ Canada Department of Finance, News Release 2009-103: “Backgrounder”, 27 October 2009.
} 
or plan sponsor's insolvency. The target funding level should also take into account the relative degree of conservatism in the valuation methodology..

In the UK scheme trustees are required to set minimum funding targets that are based on a prudent assessment of the liabilities of the scheme. These are set on a scheme specific basis taking into account the position of the plan sponsor and the level of security provided. The ability of employers to meet their obligations should be viewed in the context of the scheme's exposure to risk and volatility - for example from investment returns and demographic change. Where scheme trustees choose to accept these risks, they should be confident that the employer will be able to make additional contributions to compensate against adverse outcomes. Trustees are expected to have a framework for assessing and reviewing the covenant and should regard this as just as important to the security of the scheme as monitoring fund performance.

Some countries like Denmark and the Netherlands have linked minimum funding requirements to pension funds' investment strategies. These countries' funding rules require each pension fund to make a quantitative assessment of its risk profile in order to determine the required contribution levels and required funding buffers. Funds with riskier and more volatile assets are required to hold larger funding buffers. The most positive aspect of the approach taken in these countries is that the funding rules encourage (in these countries actually require) the accumulation of surpluses, which is desirable when company finances are strong and market conditions are positive. The downside is that a strict quantitative and risk-based approach can lead to procyclical contribution and investment strategies during periods of market turbulence. As the performance of risky assets deteriorates during a downturn and funding levels worsen, pension funds may consider reducing their exposure to such assets in order to improve their riskbased solvency indicator. Contribution requirements can also go up substantially during such periods. The potential for procyclicality is greatest when such rules are accompanied by a mark-to-market approach to calculating pension assets and liabilities using spot rates.

\section{(iii) Allow Appropriate Levels of Over-Funding in Good Economic Times via More Flexible Tax} Ceilings

High funding levels in good times can act as a buffer in bad times when as a result of adverse market conditions a double shock can occur with liabilities rising as a result of lower discount rates (a result of a "flight to safety") while asset values plunge. Hence, a regulatory approach that expects increased contributions when plan sponsor finances are strong may be appropriate. With some marked exceptions like Denmark and the Netherlands, there is little evidence of policymakers moving in this direction. Part of the problem lies in the fact that overfunding is often discouraged by tax rules.

Many countries restrict the amount that tax-favored contributions are allowed to exceed the annual minimum required level and some, like Canada, Japan and the United States, set a ceiling on the funding level, requiring that contributions stop or become nondeductible for tax purposes when the level is reached. These restrictions are intended to keep plan sponsors from using pension funds as a way to avoid paying taxes. However, such restrictions meant to protect tax revenues should be careful not to inhibit plan sponsors to, in good faith, build up a sufficiently generous surplus margin to act as a cushion during difficult economic times. One possibility that could be explored in the wider context of countryspecific regulation, is for maximum contribution or funding ceilings to span and be smoothed over a multi-year period rather than be set on an annual basis to allow greater management of cash-flows by the plan sponsor. Governments should also consider raising the maximum level of surplus before contributions must be suspended. Another idea would be that rather than setting maximum funding limits based on marked-to-market surplus levels, governments could introduce some degree of smoothing into the maximum limit as well, for instance by setting the maximum funding limit as a specific percent above the smoothed minimum funding requirement. 
The Canadian government recently proposed to raise this ceiling from $10 \%$ of the ongoing liabilities to $25 \% .{ }^{16}$ While welcome, Canada would still have a lower ceiling compared to Japan, where it is set at $150 \%$ of actuarial liabilities and the United States, where the tax deductibility of contributions ceases when assets exceed $150 \%$ of the accrued liability (for ongoing plans) plus a projection for compensation increases or, for plans whose benefits are not based on compensation, increase in benefits that are expected to occur based on recent history.

\section{(iv) Limit Contribution Holidays and Plan Sponsor Access to Surplus}

Permitting overfunding is not sufficient. In many jurisdictions there are disincentives or insufficient incentives in place to build such buffers in the first place. Plan sponsors often seek to take contribution holidays as soon as the regulatory minimum funding level is reached. Regulators should therefore consider restricting the extent to which plan sponsors can take contribution holidays, offer additional benefits or withdraw a portion of pension fund surplus, for example, only allowing them when a certain level of funding above the minimum level is reached. Regulators could also require that any such surplus reducing actions is introduced in a gradual fashion, reducing the risk of a quick depletion of the buffer.

Brazil is one country with a funding rule in place that does not allow any surplus-reduction action before a funding buffer is built up. Brazil does not require funding above $100 \%$ of liabilities on an ongoing basis, but if a surplus emerges it must be assigned to a "contingency reserve". Up to $25 \%$ of the liabilities may be stored in this reserve. When the assets exceed $125 \%$ of these liabilities, the excess becomes a "special reserve" and can be used to reduce or suspend employee and employer contributions, improve plan benefits and/or be withdrawn from the fund. If the special reserve exists for three or more years, then the special reserve must be used for these purposes.

A controversial feature of the Brazilian system is the possibility for employers to withdraw part of the surplus. The introduction of the new funding rules was contested by labour unions before the reform and there is still much opposition to the surplus rules. South Africa also saw a heated debate between labour and employers on the issue of surplus ownership as by the end of the 1990's the average defined benefit plan had a funding level on the order of $115 \%$. In response to this, the government drafted legislation on surplus ownership following these principles: (i) reward should be commensurate with the risk that each stakeholder experienced; (ii) deficits must be funded; (iii) a fair minimum benefit must be accorded to members. The intentions and principles behind the legislation were quite clear, but there have been challenges putting the law into practice and there are a large number of surplus apportionment cases still pending. ${ }^{17}$

In most OECD countries, plan sponsors generally have very little access to the plan surplus. Some notable exceptions are Ireland, Netherlands, Portugal and Sweden. Ireland only requires that the extent and modality of surplus withdrawal is stipulated in the plan rules. In the Netherlands, this is complemented with legal requirements to ensure that all members have received full (indexed) benefits in the last 10 years before the surplus withdrawal. In Portugal, surplus withdrawal is allowed as long as it is deemed to be "structural", that is, if it has lasted at least five years above a specific level.

In the United States, return of surplus to the employer is possible, although heavily taxed. A tax qualified transfer of excess assets to a separate retiree medical account within the plan may be made in

\footnotetext{
${ }^{16}$ Canada Department of Finance, News Release 2009-103: “Backgrounder”, 27 October 2009.

17 The article "Pension Fund Surpluses in South Africa" by Marius du Toit, Chief Actuary of the Financial Services Board of South Africa, was written for the Society of Actuaries.
} 
order to fund retiree health benefits. Typically, this means the excess of the plan's assets over 125 percent of the plan's funding target.

Some countries also have different rules depending on whether the surplus withdrawal is applied to an ongoing or a terminated plan. Recently, a court case in the province of Ontario in Canada concluded that the plan sponsor could use the surplus of the DB pension plan which was closed to new entrants to pay contributions for newer employees of the plan sponsor who all belonged to a separate DC component, but within the same pension plan. A concern raised was that the judgement will give plan sponsors that extra incentive to close the DB plan and "raid" the surplus for the purpose of paying for the often less generous and less secure DC pension plan. ${ }^{18}$

Canadian private pension policymakers have been very active over the last year debating proposals on various aspects of the regulatory framework, and in particular the funding rules. Ontario's Expert Commission on Pensions ${ }^{19}$ and the Canadian federal government ${ }^{20}$ have separately proposed reforms to the funding rules that resemble some aspects of the Brazilian system. Ontario's Commission recommended that sponsors are allowed to withdraw surplus from an ongoing plan if it is funded at more than $125 \%$ on a solvency basis and that contribution reductions or holidays are only allowed if the plan is more than $105 \%$ funded on a solvency basis. The federal government, which regulates about $7 \%$ of Canadian DB plans, has proposed to restrict an employers' ability to take a contribution holiday unless the pension plan is more than fully funded by a solvency margin, which will be set at a level of 5 percent of solvency liabilities. Furthermore, the Canadian Institute of Actuaries has recommended the government allow employer plan sponsors to set up special buffer accounts, "Pension Security Trusts", similar to the system currently in place in Brazil. ${ }^{21}$ Any plan funding above a pre-set margin would go into these buffer accounts, and should subsequent actuarial valuations show that plan surpluses are sufficiently large, then funds from the buffer accounts could be returned to the plan sponsor.

In order to enhance benefit security, regulations should strictly limit plan sponsors' access to the surplus. However, when plan sponsors are fully responsible to fill deficits in DB plan financing, partial, restricted access to pension fund surplus above a specific level of overfunding could create an incentive for plan sponsors to increase or at least maintain funding buffers. Such access could be complemented with restrictions on the extent to which employers with overfunded DB plans can reduce contributions and take contribution holidays, as is done in Brazil and as has been proposed in Canada. Plan sponsor access to pension fund surplus, is however, very controversial and it may be difficult to agree on a rule that satisfies the different stakeholders. In certain jurisdictions, maintaining the prohibition of surplus withdrawal may be a preferable solution to reopening the debate over the ownership of the surplus.

\section{(v) Encourage Stability of Long-Term Contribution Patterns via Appropriate Actuarial Methods}

One of the main reasons for plan sponsors abandoning or freezing DB plans in favor of DC plans is the volatile nature of required contributions and the volatile effect of pension plan costs on the plan sponsor's financial statement. DC plans do not necessarily have lower costs than DB plans, but they do

${ }^{18}$ See article, "Court OKs pension-surplus diversion Supreme Court ruling comes as more firms switch to defined contribution plans", Ottawa Citizen, August 8, 2009

${ }^{19}$ See “A Fine Balance: Safe Pensions, Affordable Plans, Fair Rules - Summary”, Report of the Expert Commission on Pensions. Ontario, 2008.

${ }^{20}$ Canada Department of Finance, News Release 2009-103: “Backgrounder”, 27 October 2009.

21 "Retooling Canada's ailing Pension System Now, For the Future: Canada's Actuaries Advocate Change", Canadian Institute of Actuaries, October 2009. 
generally have more predictable contribution levels that (as has been seen during the recent financial crisis) can sometimes be reduced or stopped altogether at the plan sponsors discretion.

Plan sponsors offering DB contributions do not generally have the option to halt or decrease contributions when the economic climate is difficult. Required contributions to DB systems are generally directly linked to the funded status of a DB plan and they are notoriously difficult to predict. That said, there are means to smooth contributions to DB plans and to dampen their volatility. There is a wide variety of actuarial funding methods and valuation methods, which differ in their degree of transparency and on their impact on the schedule and volatility of contribution levels. ${ }^{22}$ It is important to note, however, that the total ultimate cost of a pension plan is dependent on the level of benefits promised. The ultimate cost is not affected by the actuarial cost method that is chosen. All that the actuarial cost method does is allocate a portion of the total ultimate cost of the pension scheme to each fiscal year throughout the life of the scheme.

Actuarial funding methods should foremost be transparent. Actuarial funding methods that lead to sensible and smooth contribution patterns could be encouraged by regulators, although the specifics of a country's pension system must be taken into account. For example, in Sweden pension costs in the main collectively bargained DB plan that covers 700,000 white-collar workers are required to be made using an actuarial cost method that spreads the cost of salary increases over employees' remaining years until retirement. This means that young people have very low pension costs whereas old people are significantly more expensive, especially should they receive a large pay increase. As Swedish DB accruals are directly linked to pension costs, this actuarial cost method is required in the collective agreement and would be difficult to change without restructuring the pension system.

That said, even in jurisdictions where a range of actuarial funding methods are available, plan sponsors often chose the straight-forward, yet somewhat volatile "projected unit method" for funding purposes since that method is typically required for accounting valuations.

\section{(vi) Flexible Funding Rules that Reflect the Overall Volatility of Funding Valuations}

Actual experience in pension plans will always differ from the assumptions made in an actuarial valuation. For instance, the number of people who leave the company in a year or the level of salary increases will differ from what was assumed. This means that actuarial gains and losses will arise which must somehow be reflected into the funding contributions of the plan sponsor. There are various ways to finance gains and losses, however, most jurisdictions specify some type of period over which such additional costs or savings are amortized.

Generally, there is a need for flexibility in funding rules. Plan member security must be maintained, but funding regulations should be structured so as not to put undue pressure on plan sponsors at times when their own profitability or even continuity is under pressure. For instance, the recovery periods required to eliminate funding deficits in DB plans should reflect the overall volatility of funding levels. If there is very little smoothing for purposes of calculating the level of funding the plan, it would make sense to allow plan sponsors a longer period to amortize the costs of volatile changes in assets and liabilities. If a great deal of smoothing is allowed, a shorter amortization period may be appropriate. The level of flexibility of funding rules will also depend on other factors such as the extent to which the fund can rely on additional plan sponsor contributions.

\footnotetext{
${ }^{22}$ See Colin Pugh, "Funding Rules and Actuarial Methods", OECD Working Paper on Insurance and Private
} Pensions, No 1, October 2006. 
Flexibility in eliminating funding deficits can be complemented with other enhancements to plan member security such as introducing insurance against sponsor bankruptcy and giving plan members priority creditor status. Another arrangement that could be explored is possibility for plan sponsors to formally earmark corporate assets for the pension plan without the requirement that the plan sponsor lock those assets into the actual pension fund through contributions. For example, contingent assets could be identified that would transfer from the employer plan sponsor to the pension scheme under certain prescribed conditions. Any such flexible funding arrangements would need to be properly controlled to makes sure it was not abused.

In 2009, the Canadian government consulted on, and ultimately proposed to permit pension plan sponsors to use properly structured letters of credit to satisfy solvency payments up to a limit of 15 percent of plan assets. Letters of credit would provide for a payment of their face value to the pension fund upon the occurrence of a pre-specified event. Letters of credit are intended to provide a comparable level of security to plan members as regular cash funding. By using letters of credit, sponsors would not be required to remit cash amounts to the fund. Furthermore, should the plan achieve a funded position sufficient to no longer require the value of letters of credit to achieve a fully funded position, sponsors would be permitted to withdraw excess letters of credit. ${ }^{23}$

The UK is an example of this flexible funding regime. The UK's funding regime balances prudent assumptions focused on the primacy of technical provisions and a reasonable judgment of affordability in agreeing recovery plans. It allows for flexibility in setting funding levels and recovery plans on a scheme specific level. In 2005, the UK introduced a flexible funding approach that eliminated prescriptive minimum funding rules in favor of flexible, scheme-specific and principles-based funding guidance. Rather than follow very specific valuation rules, the plan trustees must decide on an actuarial funding method, economic and demographic assumptions that are prudent and allow for an appropriate margin for poor experience and must decide on an appropriate recovery plan. Like Canada, the United Kingdom also allows letters of credit for funding purposes as well as other tools like contingent assets. The introduction of these funding requirements was a major policy shift in the United Kingdom and introduced much more flexibility in how pension promises are financed. The Pensions regulator publishes regular guidance to support understanding of the rules and regulations. This has included guidance on the use of contingent assets. Together with these new funding rules, the United Kingdom established the Pension Protection Fund.

\section{(vii) Avoid Over-regulation and Maintain a Stable Regulatory Environment}

The regulatory framework needs to be robust in order to provide a high degree of benefit protection. It is also important to strike the right balance between stability and flexibility in funding rules. Changing rules too frequently can lead to additional volatility in pension funding. Plan sponsors crave predictability, stability and simplicity in funding and accounting rules. DB systems are significantly more complex and are often more expensive to administer than DC systems. Policymakers should avoid continuously changing and excessively complex regulation as this could discourage plan sponsors from making long-term pension promises.

The United Kingdom is an example of a country where regulation had been tightening over the years, increasing both the benefits and administrative costs of DB plans for plan sponsors and creating much policy uncertainty. The reform of funding rules was an important step in making regulations more flexible for DB plans. Recently, the UK government announced that they intend to further deregulate DB pensions: "The aim ... is to make the private pensions regulatory framework simpler. It will seek to recommend

${ }^{23}$ Currently, the Canadian provinces of Alberta, British Columbia and Quebec permit letters of credit to be used in this fashion. 
changes for the future that will make running schemes easier, lighten regulation and reduce bureaucracy and cost. It will consider a range of measures affecting both administrative costs and the costs of provision." ${ }^{24}$ A public consultation on this matter was completed in December 2008 and various changes are at different stages of further consideration and implementation.

\section{Is Convergence of Funding Regulations an Achievable Goal?}

Funding regulations across OECD countries vary widely and reflect the differences in culture, the history of pension provisions and the level of safety provided by countries' social protection programmes. The European Union introduced some overarching principles and high-level regulations to member countries in their 2003 Directive for Institutions for Occupational Retirement Provisions. The Directive was fully implemented by member states in 2007. Some general principles such as full funding based on some type of market discount rate and applying the "prudent person principle" to investment regulations are required, but how local legislation put these overarching principles into practice are still very different across jurisdictions.

Article 16 of the 2003 Directive requires full-funding for pension schemes, although the technicalities of this requirement are not detailed in the Directive. The European Union has tried to clarify this requirement in particular for pension systems that operate across national borders. The feedback document on the public consultation published in March $2009^{25}$ stated that there was general agreement that further harmonization for the valuation of technical provisions was appropriate, but on a principles basis rather than a prescriptive rules basis. Some of the key obstacles identified were differences in legal interpretations of cross-border activity, differences in national social and labour laws and different tax regimes.

A major stumbling block to greater convergence in funding regulations is that DB plans differ in the form of benefit protection offered, while policymakers have different attitudes to the extent of benefit security that should be reached. In most countries, underfunding of DB plans is the responsibility of plan sponsors and in some countries there are pension protection schemes to protect benefits (usually up to a certain level only) in case of bankruptcy of the plan sponsor. Such countries may allow (under certain conditions) underfunding to continue for many years, and in a very limited number of countries it may even be a permanent feature of the system. In contrast, in countries where pension promises are the responsibility of the pension company (and hence plan members), as in Denmark and to some extent the Netherlands, funding regulations tend to be more strict.

Attitudes to benefit security also differ between countries, partly because of cultural differences, but also because of the nature of participation in private pension plans and the extent to which lower income employees are covered. For instance, in Denmark and the Netherlands, private pension plans are a central component of the retirement income, covering the vast majority of employees. They also complement relatively low public pension plans, making the security of private pension promises a central policy concern.

International standardization of funding regulations is therefore unlikely and such standardized regulation would risk being ill-fitting across jurisdictions. However, some convergence of over-arching funding principles to promote counter-cyclical features as discussed in this paper could strengthen DB systems. This could be complemented by general international best-practices and guidelines on how to

\footnotetext{
${ }^{24}$ Department of Work and Pension website, http://www.dwp.gov.uk/policy/pensions-reform/deregulatory-review/

${ }^{25}$ European Commission, Feedback Statement: Consultation on the Harmonisation of Solvency Rules Applicable to Institutions for Occupational Retirement Provision (IORP) Covered by Article 17 of the IORP Directive and IORPs Operating on a Cross-Border Basis, Brussels, 16 March 2009
} 
determine minimum funding contributions and assets and liabilities and by further developing the OECD Guidelines on Funding and Benefit Security. Such principle-based convergence in funding regulations could facilitate the development of cross-border pension activity and facilitate international comparisons of funding levels. However, any such broad principles or guidance must be respectful of the legislative, labour and social reality at the local level. An attempt to create specific legislation to be applied to all OECD countries would be counter-productive and unrealistic. 
APPENDIX I: OVERVIEW OF PENSION FUNDING REGULATIONS IN SELECT OECD COUNTRIES

\begin{tabular}{|c|c|c|c|c|}
\hline Country & Accrued liabilities / Technical Provisions & $\begin{array}{c}\text { Discount rate and other economic } \\
\text { assumptions }\end{array}$ & $\begin{array}{c}\text { Minimum funding, including the } \\
\text { Maximum Allowable } \\
\text { Amortisation Period }\end{array}$ & $\begin{array}{c}\text { Maximum Funding Rules and } \\
\text { Access to Surplus for an ongoing } \\
\text { plan }\end{array}$ \\
\hline Belgium & $\begin{array}{l}\text { The calculation of technical provisions must be } \\
\text { prudent and take into account the risk profile of the } \\
\text { pension fund (IORP). Furthermore, the technical } \\
\text { provisions must at least equal the vested reserves, } \\
\text { which are determined by the pension plan rules and } \\
\text { the Social and Labour law. When Belgian social } \\
\text { legislation is applicable the technical provisions } \\
\text { must at least be the maximum of vested rights as } \\
\text { defined in the plan rules and own contributions } \\
\text { accumulated with an interest rate of } 3.75 \% \text {. } \\
\text { Minimum vested rights are calculated on the basis } \\
\text { of current salaries with an interest rate of } 6 \% \text { and } \\
\text { specific mortality tables (MR } 88-90 \text { table for males } \\
\text { and the FR } 88-90 \text { table for females). }\end{array}$ & $\begin{array}{l}\text { Belgian prudential legislation: the } \\
\text { discount rate for the calculation of } \\
\text { the technical provisions has to be } \\
\text { chosen in a prudent manner and } \\
\text { taking into account: (i) the return on } \\
\text { covering assets as well as future } \\
\text { returns and/or (ii) the return on } \\
\text { bonds of a Member State or on other } \\
\text { high-quality bonds. }\end{array}$ & $\begin{array}{l}\text { Minimum Funding: } \begin{array}{l}100 \% \text { of } \\
\text { provisions }\end{array} \\
\text { technical } \\
\text { Maximum Allowable Amortisation } \\
\text { Period: Not specified. In case of } \\
\text { underfunding, a recovery plan which } \\
\text { takes into account the risk profile of } \\
\text { the pension fund (IORP) must be } \\
\text { submitted to and approved by the } \\
\text { regulator (CBFA). It is up to the } \\
\text { pension fund to decide itself on the } \\
\text { most appropriate recovery plan, but } \\
\text { it has to be approved by the CBFA }\end{array}$ & $\begin{array}{l}\text { There are no direct limits on the } \\
\text { maximum amount of assets that can } \\
\text { be held in a pension fund. However, } \\
\text { there are two indirect constraints: } \\
\text { - The maximum pension that can } \\
\text { be provided under a tax-effective } \\
\text { Belgian pension plan is } 80 \% \text { of final } \\
\text { salary after a full career ad inclusive } \\
\text { of Social Security benefits. } \\
\text { - The financing plan prepared by } \\
\text { the actuary and submitted to the } \\
\text { insurance control authorities must } \\
\text { take account of the } 80 \% \text { limit. } \\
\text { The plan sponsor is not allowed to } \\
\text { withdraw excess assets from the } \\
\text { fund. }\end{array}$ \\
\hline
\end{tabular}




\begin{tabular}{|c|c|c|c|c|}
\hline Country & Accrued liabilities / Technical Provisions & $\begin{array}{l}\text { Discount rate and other economic } \\
\text { assumptions }\end{array}$ & $\begin{array}{c}\text { Minimum funding, including the } \\
\text { Maximum Allowable } \\
\text { Amortisation Period }\end{array}$ & $\begin{array}{l}\text { Maximum Funding Rules and } \\
\text { Access to Surplus for an ongoing } \\
\text { plan }\end{array}$ \\
\hline Canada $^{26}$ & Plan termination liability (current unit credit) & $\begin{array}{l}\text { Interest rate of } x \% \text { per annum for } 10 \\
\text { years and } y \% \text { per annum thereafter. } \\
\text { The rate "x" is equal to the } \\
\text { annualised market yield on } 7 \text {-year } \\
\text { Government of Canada benchmark } \\
\text { bonds plus } 90 \text { basis points. The rate } \\
\text { "y" is a more complicated blend of } \\
\text { market yields on such } 7 \text {-year bonds } \\
\text { and on long term Government of } \\
\text { Canada benchmark bonds, again } \\
\text { plus } 90 \text { basis points. Lower interest } \\
\text { rates apply when the plan provides } \\
\text { indexation of pensions; the formulas } \\
\text { are specified in the CIA Standards of } \\
\text { Practice. }\end{array}$ & $\begin{array}{l}\text { Minimum Funding: Two tests must } \\
\text { be met. (i) } 100 \% \text { funding of going } \\
\text { concern liabilities under the selected } \\
\text { actuarial costing method (e.g. PBO } \\
\text { under projected unit credit method). } \\
\text { (ii) } 100 \% \text { of solvency liabilities. } \\
\text { Solvency liabilities assume the plan } \\
\text { terminates and are generally greater } \\
\text { than going concern liabilities. } \\
\text { Maximum Allowable Amortisation } \\
\text { Period: For going concern liabilities, } \\
15 \text { years. For solvency liabilities, } \\
\text { the amount by which the solvency } \\
\text { deficiency divided by } 5 \text { exceeds the } \\
\text { amount of the going concern special } \\
\text { payments payable during the plan } \\
\text { year. }\end{array}$ & $\begin{array}{l}\text { There is a maximum funding limit } \\
\text { under the tax rules. Should the } \\
\text { surplus exceed a specified threshold } \\
\text { (generally } 25 \text { per cent as determined } \\
\text { on a going concern basis), employer } \\
\text { current service contributions must } \\
\text { generally be suspended. } \\
\text { Surplus withdrawal is allowed } \\
\text { although it is difficult for a plan to } \\
\text { withdraw surplus assets from a fund } \\
\text { in an ongoing situation as it } \\
\text { requires clear employer entitlement } \\
\text { in historical plan documentation } \\
\text { or members' approval. If a plan is } \\
\text { terminated, allocation of surplus } \\
\text { funds is dependent on the plan } \\
\text { text or on receiving agreement from } \\
\text { the required number of plan } \\
\text { members and beneficiaries. }\end{array}$ \\
\hline Finland & $\begin{array}{l}\text { Accrued benefits calculated under current unit } \\
\text { credit method }\end{array}$ & $3.5 \%-3.8 \%$ depending on the plan & $\begin{array}{l}\text { Minimum Funding: } 100 \% \text { of } \\
\text { technical provisions, no solvency } \\
\text { margin }\end{array}$ & \\
\hline
\end{tabular}

${ }^{26}$ The information for Canada in this table applies to defined benefit pension plans regulated at the federal level. Provincially regulated plans may have different requirements, particularly for the maximum allowable amortisation period. 


\begin{tabular}{|c|c|c|c|c|}
\hline Country & Accrued liabilities / Technical Provisions & $\begin{array}{l}\text { Discount rate and other economic } \\
\text { assumptions }\end{array}$ & $\begin{array}{c}\text { Minimum funding, including the } \\
\text { Maximum Allowable } \\
\text { Amortisation Period } \\
\end{array}$ & $\begin{array}{c}\text { Maximum Funding Rules and } \\
\text { Access to Surplus for an ongoing } \\
\text { plan }\end{array}$ \\
\hline Germany & $\begin{array}{l}\text { The technical provisions are the present value of the } \\
\text { future liabilities minus the present value of the } \\
\text { future premiums. The valuation of liabilities } \\
\text { includes salary increases or inflation revaluation } \\
\text { between the valuation date and retirement age if } \\
\text { these are included in the pension promise. }\end{array}$ & $\begin{array}{l}\text { The maximum discount rate for } \\
\text { Pensionskassen and Pensionsfonds } \\
\text { (if the latter offer insurance-like } \\
\text { guarantees) is currently } 2.25 \% \text { for } \\
\text { new schemes. Pensionsfonds can use } \\
\text { market interest rates on a best } \\
\text { estimate basis if they offer no } \\
\text { insurance-like guarantees. }\end{array}$ & 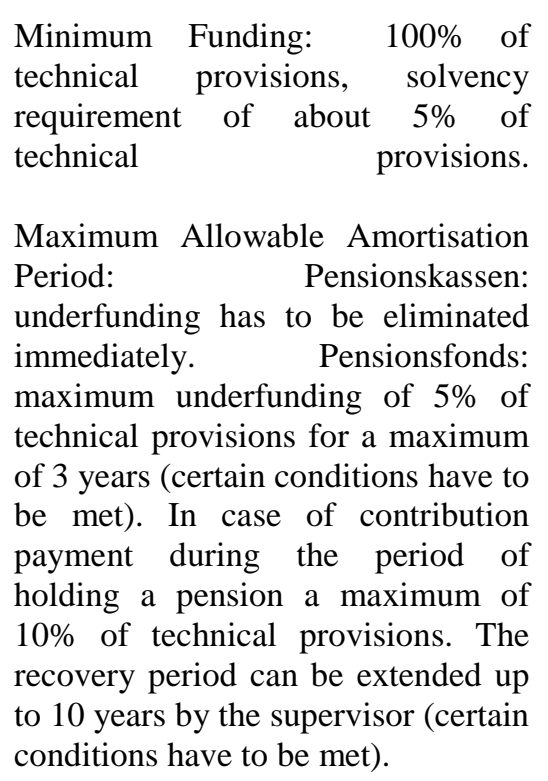 & \\
\hline Ireland & $\begin{array}{l}\text { Plan termination liability (current unit credit), } \\
\text { including mandatory revaluation of benefits with } \\
4 \% \text { cap, until retirement }\end{array}$ & $\begin{array}{l}\text { (a) a pre-retirement discount rate of } \\
7.50 \% \text {; (b) a long term post- } \\
\text { retirement discount rate of } 4.50 \% \text {; } \\
\text { (c) a pre-retirement price inflation } \\
\text { rate of } 2.00 \% \text {; and (d) a post- } \\
\text { retirement long term rate of price } \\
\text { inflation of } 2.00 \% \text {. }\end{array}$ & $\begin{array}{l}\text { Minimum Funding: } 100 \% \text { of } \\
\text { technical provisions, no solvency } \\
\text { margin }\end{array}$ & $\begin{array}{l}\text { There are no direct quantitative } \\
\text { limits concerning the maximum } \\
\text { amount of assets that can be held in } \\
\text { a pension fund. The tax authorities } \\
\text { must be informed when the surplus } \\
\text { reaches } 10 \% \text {. } \\
\text { Surplus withdrawal allowed subject } \\
\text { to plan's rules. In the event of a } \\
\text { termination of an overfunded plan, }\end{array}$ \\
\hline
\end{tabular}




\begin{tabular}{|c|c|c|c|c|}
\hline Country & Accrued liabilities / Technical Provisions & $\begin{array}{c}\text { Discount rate and other economic } \\
\text { assumptions }\end{array}$ & $\begin{array}{l}\text { Minimum funding, including the } \\
\text { Maximum Allowable } \\
\text { Amortisation Period }\end{array}$ & $\begin{array}{l}\text { Maximum Funding Rules and } \\
\text { Access to Surplus for an ongoing } \\
\text { plan }\end{array}$ \\
\hline & & & & $\begin{array}{l}\text { plan surplus are allocated according } \\
\text { to existing pensions law. }\end{array}$ \\
\hline Japan & Plan termination liability (current unit credit) & $\begin{array}{l}80-120 \% \text { of } 10 \text {-year government } \\
\text { bonds issued during the previous } 5 \\
\text { years. }\end{array}$ & $\begin{array}{l}\text { Minimum Funding: } \\
\text { of contracted-out portion, } 5 \% \\
\text { solvency margin; } 90 \% \text { funding for } \\
\text { total blan }\end{array}$ & $\begin{array}{l}\text { The prescribed upper limit on } \\
\text { funding is } 150 \% \text { of actuarial } \\
\text { liabilities. } \\
\text { Surplus withdrawal not allowed. }\end{array}$ \\
\hline Netherlands & $\begin{array}{l}\text { Accrued benefits calculated under current unit } \\
\text { credit method }\end{array}$ & $\begin{array}{l}\text { Discount rate for the valuation of } \\
\text { liabilities is based on swap rates. } \\
\text { Smoothing is allowed for } \\
\text { determining contributions. }\end{array}$ & $\begin{array}{l}\text { Minimum Funding: } 100 \% \text { of } \\
\text { technical provisions, solvency } \\
\text { margin of } 5 \% \text {, risk-based reserve, } \\
\text { fund-dependent, averaging about } \\
30 \% \text { of accrued liabilities inclusive } \\
\text { of } 5 \% \text {. } \\
\text { Maximum Allowable Amortisation } \\
\text { Period: } 3 \text { years for solvency margin } \\
\text { (temporarily increased to } 5 \text { years), } \\
15 \text { years for buffer. }\end{array}$ & $\begin{array}{l}\text { There is no maximum funding rule. } \\
\text { Surplus withdrawal allowed } \\
\text { according to plan rules, within legal } \\
\text { limitations. }\end{array}$ \\
\hline
\end{tabular}




\begin{tabular}{|c|c|c|c|c|}
\hline Country & Accrued liabilities / Technical Provisions & $\begin{array}{c}\text { Discount rate and other economic } \\
\text { assumptions }\end{array}$ & $\begin{array}{c}\text { Minimum funding, including the } \\
\text { Maximum Allowable } \\
\text { Amortisation Period }\end{array}$ & $\begin{array}{c}\text { Maximum Funding Rules and } \\
\text { Access to Surplus for an ongoing } \\
\text { plan }\end{array}$ \\
\hline Norway & $\begin{array}{l}\text { Accrued benefits calculated under current unit } \\
\text { credit method }\end{array}$ & $\begin{array}{l}4 \% \text { discount rate until } 1993 \text {. For } \\
\text { contributions due after } 1 \text { January } \\
2004 \text { and pension funds established } \\
\text { after } 1993 \text { the maximum rate is } 3 \% \text {, } \\
2.75 \% \text { for new contracts after } 2006 \text {. }\end{array}$ & $\begin{array}{l}\text { Minimum Funding: } 100 \% \text { of } \\
\text { technical provisions, solvency } \\
\text { margin of } 8 \% \text { of the total risk- } \\
\text { weighted asset items and off-balance } \\
\text { sheet } \\
\text { items. } \\
\begin{array}{l}\text { Maximum Allowable Amortisation } \\
\text { Period: Immediate action, but } \\
\text { period not specified. }\end{array}\end{array}$ & $\begin{array}{l}\text { No maximum funding rules apply. } \\
\text { When a terminated plan is } \\
\text { overfunded, surplus assets are } \\
\text { normally applied to enhance } \\
\text { member benefits. }\end{array}$ \\
\hline Portugal & $\begin{array}{l}\text { Accrued benefits calculated under current unit } \\
\text { credit method. If indexing of pensions is } \\
\text { contractually guaranteed, then an allowance for the } \\
\text { effect of future indexing must be included in the } \\
\text { calculation of the accrued liabilities. }\end{array}$ & $4.50 \%$ & $\begin{array}{l}\text { Minimum Funding: } 100 \% \text { of } \\
\text { technical provisions, no solvency } \\
\text { margin } \\
\text { Maximum Allowable Amortisation } \\
\text { Period: Not specified. A plan to } \\
\text { eliminate any underfunding must be } \\
\text { submitted to the regulator. The } \\
\text { effect of changes in regulation can } \\
\text { be amortised over } 20 \text { years. }\end{array}$ & $\begin{array}{l}\text { There are no direct limits on the } \\
\text { maximum amount of assets that can } \\
\text { be held in a pension fund, but there } \\
\text { are limits on employer contributions } \\
\text { for tax purposes. } \\
\text { A plan sponsor can request prior } \\
\text { approval for a return of surplus, } \\
\text { which will only be possible if the } \\
\text { surplus exists for structural reasons } \\
\text { over five consecutive years and } \\
\text { annually exceeds a set percentage of } \\
\text { the accrued liabilities. }\end{array}$ \\
\hline Spain & $\begin{array}{l}\text { Projected Benefit Obligation (including salaries at } \\
\text { retirement - projected unit credit method) }\end{array}$ & $\begin{array}{l}4 \% \text { discount rate. Inflation } \\
\text { assumption of } 1.5-2.0 \% .\end{array}$ & $\begin{array}{l}\text { Minimum Funding: } 100 \% \text { of } \\
\text { technical provisions, } 4 \% \text { solvency } \\
\text { margin } \\
\text { Maximum Allowable Amortisation } \\
\text { Period: Up to } 5 \text { years (extendable to } \\
10 \text { by the supervisor). }\end{array}$ & $\begin{array}{l}\text { No maximum funding rules apply. } \\
\text { In the case of an overfunded plan, } \\
\text { the plan rules specify how the excess } \\
\text { assets should be allocated. }\end{array}$ \\
\hline
\end{tabular}




\begin{tabular}{|c|c|c|c|c|}
\hline Country & Accrued liabilities / Technical Provisions & $\begin{array}{l}\text { Discount rate and other economic } \\
\text { assumptions }\end{array}$ & $\begin{array}{c}\text { Minimum funding, including the } \\
\text { Maximum Allowable } \\
\text { Amortisation Period }\end{array}$ & $\begin{array}{c}\text { Maximum Funding Rules and } \\
\text { Access to Surplus for an ongoing } \\
\text { plan }\end{array}$ \\
\hline Switzerland & $\begin{array}{l}\text { Accrued benefits calculated under current unit } \\
\text { credit method }\end{array}$ & & $\begin{array}{l}\text { Minimum Funding: } 90 \% \text { funding of } \\
\text { technical provisions. Fluctuation } \\
\text { reserves are actively encouraged. } \\
\text { There is no legal obligation on } \\
\text { employers to increase contributions } \\
\text { in case of underfunding. Benefits } \\
\text { would be adjusted if underfunding is } \\
\text { not corrected within the required } \\
\text { recovery period. } \\
\text { Maximum Allowable Amortisation } \\
\text { Period: Less than } 10 \text { years. } \\
\text { Normally, 5-7 years }\end{array}$ & $\begin{array}{l}\text { There are no direct limits on } \\
\text { maximum funding. However, there } \\
\text { are upper limits on the benefits that } \\
\text { can be provided and the tax- } \\
\text { deductible contributions that can be } \\
\text { made to plans. There is a certain } \\
\text { (undefined) extent of margin before } \\
\text { tax exemption is withdrawn. } \\
\text { Surplus withdrawal is not allowed. }\end{array}$ \\
\hline $\begin{array}{l}\text { United } \\
\text { Kingdom }\end{array}$ & $\begin{array}{l}\text { Accrued benefits must be calculated on a prudent } \\
\text { basis }\end{array}$ & $\begin{array}{l}\text { The discount rate in the UK can } \\
\text { broadly be described by the } \\
\text { following equation: discount rate = } \\
\text { risk free rate + risk premium } \\
\text { A proxy such as a government bond } \\
\text { yield is typically used for the spread } \\
\text { over the risk free rate is assumed, } \\
\text { typically based on: the time horizon } \\
\text { of liabilities; the potential for } \\
\text { additional investment return; and a } \\
\text { prudence adjustment, based on the } \\
\text { employer's covenant. }\end{array}$ & $\begin{array}{l}\text { There is no minimum funding } \\
\text { requirement or recovery periods, but } \\
\text { the regulator will pay specific } \\
\text { attention to recovery plans longer } \\
\text { than ten years to reach full funding } \\
\text { of the liability. }\end{array}$ & $\begin{array}{l}\text { There is no maximum funding limit. } \\
\text { Surplus withdrawal is possible if } \\
\text { funding up to buy-out level and } \\
\text { trustees' approval required (must be } \\
\text { in best interest of beneficiaries). }\end{array}$ \\
\hline
\end{tabular}




\begin{tabular}{|c|c|c|c|c|}
\hline Country & Accrued liabilities / Technical Provisions & $\begin{array}{c}\text { Discount rate and other economic } \\
\text { assumptions }\end{array}$ & $\begin{array}{c}\text { Minimum funding, including the } \\
\text { Maximum Allowable } \\
\text { Amortisation Period }\end{array}$ & $\begin{array}{c}\text { Maximum Funding Rules and } \\
\text { Access to Surplus for an ongoing } \\
\text { plan }\end{array}$ \\
\hline $\begin{array}{l}\text { United } \\
\text { States } \\
\text { (Single } \\
\text { Employer } \\
\text { Plans) }\end{array}$ & $\begin{array}{l}\text { Accrued benefits calculated under current unit } \\
\text { credit method }\end{array}$ & $\begin{array}{l}\text { Modified yield curve ( } 3 \text { segments) } \\
\text { based on a two-year average of top } 3 \\
\text { levels of high-grade corporate bonds } \\
\text { of appropriate duration. }\end{array}$ & $\begin{array}{l}\text { Minimum Funding: } 100 \% \text { of } \\
\text { technical provisions, no solvency } \\
\text { margin } \\
\text { Maximum Allowable Amortisation } \\
\text { Period: } 7 \text { years for each year's } \\
\text { funding target shortfall. }\end{array}$ & $\begin{array}{l}\text { The deductibility of contributions } \\
\text { ceases when assets exceed } 150 \% \text { of } \\
\text { the funding target (the accrued } \\
\text { liability for ongoing plans) plus a } \\
\text { projection for salary increases or } \\
\text { projected benefit increases. } \\
\text { If a plan is funded above } 125 \% \text {, } \\
\text { excess assets may be used to fund } \\
\text { retiree health benefits under certain } \\
\text { conditions. } \\
\text { Any left-over surplus from a } \\
\text { terminated plan is heavily taxed if } \\
\text { returned to the plan sponsor. }\end{array}$ \\
\hline
\end{tabular}

Source: OECD 